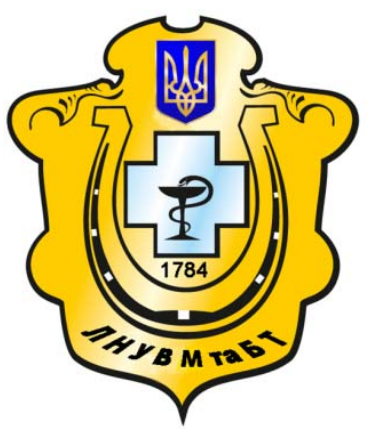

Науковий вісник Львівського національного університету ветеринарної медицини та біотехнологій імені С.3. Гжицького

Scientific Messenger of Lviv National University of Veterinary Medicine and Biotechnologies named after S.Z. Gzhytskyj

doi:10.15421/nvlvet7141

ISSN 2413-5550 print

ISSN 2518-1327 online

$\underline{\text { http://nvlvet.com.ua/ }}$

УДК 616.65-002-007.61:616.832.9-008.8-078

\title{
Чутливість збудників бактеріальних хвороб птиці до антибактеріальних препаратів
}

\author{
Г.А. Фотіна, Ж.С. Кліщова \\ tif_ua@meta.ua., Kge1990@mail.ru \\ Сумський національний аграрний університет, \\ вул. Герасима Кондратьєва, 160, м. Суми, 40000, Украӥна
}

\begin{abstract}
У статті наведено результати моніторингу сальмонельозу і колібактеріозу птиці в господарствах України. Мікробіологічний моніторинг ряду птахівничих господарств Украӥни свідчить, щяо збудники хвороб бактеріальної етіології широко розповсюдженні. Поміж ізольованої мікрофлори найбільшу кількість становили сальмонели (54,1\%) та ешерихії (30,8\%). Решту (15,1\%) становили ізольовані культури протею, синьогнійної палички, клебсієл, ієрсиній, кампілобактерій, ентеробактерій, иитробактерій та клостридій. Це вказує на необхідність систематичного контролю за наявністю збудників бактеріальних інфекцій на всіх критичних точках виробнищтва продукиії птахівництва. Поміж ізолятів, які були виділені від хворої птиці та з об'єктів птахівництва, виявили відмінності в їх чутливості до протимікробних засобів з числа АДР хіміотерапевтичних засобів, офіційно зареєстрованих у намій краӥні. Бактерицидну активність щуодо ізольованих культур виявили: колістин, фторфеніколь, цефтіокур, ТімТіл 250, доксоциклін, енроксил та сарафлоксаиин. На основі отриманих даних будуть створені та буде проведена фармако - токсикологічна оцінка хіміотерапевтичних засобів для забезпечення схем ротації вітчизняних препаратів для профілактики бактеріальних інфекцій птиці.

Ключові слова: бактерії, сальмонела, ешерихія, птиця, антибіотикорезістентність, токсичні речовини, продукти харчування.
\end{abstract}

\section{Чувствительность возбудителей бактериальных болезней птицы к антиба- ктериальным препаратам}

\author{
А.А. Фотина, Ж.Е. Клищева \\ tif_ua@meta.ua., Kge1990@mail.ru \\ Сумской национальный аграрный университет, \\ ул. Герасима Кондратьева, 160, г. Суммы, 40000, Украина
}

\begin{abstract}
В статье приведены результаты мониторинга возбудителей сальмонеллеза и колибактериоза птицы в хозяйствах Украины. Микробиологический мониторинг ряда птицеводческих хозяйств Украины свидетельствует, что возбудители болезней бактериальной этиологии широко распространены. Среди изолированной микрофлоры наибольшее количество составляли сальмонелль $(54,1 \%)$ и эшерихии $(30,8 \%)$. Остальные $(15,1 \%)$ изолированные микроорганизмы это культуры протея, синегнойной палочки, клебсиелл, иерсиний, кампилобактеров, энтеробактерий, ичитробактеры и клостридий. Это указывает на необходимость систематического контроля за наличием возбудителей бактериальных инфекиий на всех критических точках производства продукиии птицеводства. Между изолятами, выделенных от больной птии и с объектов птицеводства, обнаружили различия в их чувствительности к противомикробным средствам из числа АДР химиотерапевтических средств, официально зарегистрированных в нашей стране. Бактерицидную активность относительно изолированных культур обнаружил к колистину, фторфениколю, иефтиокуру, ТимТил 250, доксоциклину, енроксилу и сарафлоксацину. На основеполученных данных будут разроботаны и будет проведена фармако - токсикологическая оченка химиотерапевтических средств для обеспечения схем ротачии отечественных препаратов для профилактики бактериальных инфекций птищьл.
\end{abstract}

Citation:

Fotina, A.A., Klischova, Zh.E. (2016). The sensitivity of the pathogens of poultry's bacterial diseases to antibiotics. Scientific Messenger LNUVMBT named after S.Z. Gzhytskyj, 18, 3(71), 182-185. 
Ключевые слова: бактерии, сальмонелла, эиерихия, птица, антибиотикорезистентнисть, токсические вещества, продуктьл питания.

\title{
The sensitivity of the pathogens of poultry's bacterial diseases to antibiotics
}

\author{
A.A. Fotina, Zh.E. Klischova \\ tif_ua@meta.ua., Kge1990@mail.ru
}

\author{
Sumy national agricultural university, Gerasim Kondratyev Str., 160, Sumy, 40000, Ukraine
}

\begin{abstract}
The using of antibiotics and antimicrobials drugs without control may leads to the development of numerous complications and resistance of microorganisms to antibiotics. The using of antibiotics and antimicrobials drugs should are controlled on poultry farms. That is why the monitoring and determination of sensitivity of bacterial diseases agents to antimicrobial drugs are very important. Results of salmonellas' and kolibakterias' monitoring in poultry's farms of Ukraine are introduced in the article. Researches were conducted at the Department of veterinary sanitary examination, microbiology, zoohygiene and safety and quality of livestock products of Sumy NAU. Sampling for microbiological studies was conducted from the hatchery and from pathological material and premises where poultry of different age groups was held. The spread of the disease, morbidity, mortality, mortality rate, age characteristics, economic loss what diseases cause to the poultry farms were counted. Identification of Salmonella and Escherichia was conducted by ELISA with using of RIDASCREEN® and LOCATE ${ }^{\circledR}$ test systems, according to methodical recommendations of RIDASCREEN® and LOCATE ${ }^{\circledR}$ test systems using. The results were read visually or after addition of storageco with ELISAphotometer (reader) at $450 \mathrm{~nm}$. Sensitivity to antibiotics was determined by disco-diffusion method in agar. Microbiological monitoring of a number of poultry farms in Ukraine has shown that agents of bacterial diseases' are widely spread. Between the isolated microflora largest number were accounted for Salmonella (54.1\%) and the Escherichia (30.8 per cent). The rest (15,1\%) were isolated cultures of Proteus, Pseudomonas, Klebsiella, Salmonella, Campylobacteria, Enterobacteria, and Clostridia Citrobacter. This indicates that systematic control over the availability of the causative agents of bacterial infections in all critical points of production of poultry products is very necessary. Among isolates that were isolated from ill poultry and poultry objects, differences in their sensitivity to antimicrobial agents from active substances that officially have registered in our country were discovered. Bactericidal activity of relatively isolated cultures was showed by colistin, ftorfenicol, zeftiocur, TimTil 250, doxicyclin, enroxil and sarafloxacin.

Key words: bacteria, Salmonella, Escherichia, antibioticoresistanc, poultry, toxic substances, food.
\end{abstract}

\section{Вступ}

Основним біотопом бактерій родів Escherichia, i Salmonella i інших бактерій $є$ кишковик птиці. У науковій літературі останнього часу таке поєднання як паразит-господар отримав назву асоціативного симбіозу, який має свої різновиди: мутуалізм корисний для обох партнерів; коменсалізм - нешкідливий для симбіонтів i, нарешті, антагонізм - варіанти шкідливих наслідків для одного з партнерів (Borisenkova and Rozhdestvenskaja, 2003; Aleksandrov and Migaesh, 2011; Vostroilova et al., 2012; Stegnij et al., 2014). Koлонізація кишковика патогенними мікроорганізмами починається 3 їх зв'язування 3 клітинами кишкового епітелію. Безліч патогенів включаючи більшість видів економічно значущих сальмонел і ешерихій, прикріпляються до кишковика за допомогою рецепторів (фімбрій), специфічних до певних вуглеводів кишкового епітелію, що містить монозу, яку вони надалі руйнують і пригнічують корисну мікрофлору кишечнику. Тому застосування антибіотиків i протимікробних препаратів робить можливим неефективним лікування багатьох особливо небезпечних хвороб. У той же час безконтрольне застосування антибіотиків і протимікробних препаратів може привести до розвитку численних ускладнень і до резистентності мікроорганізмів до антибіотиків, що спонукає до постійного контролю їх в птахівничих господарствах (Wegener, 2009; Dvorskaja and Fotina, 2012; Fotina, 2014). Тому дуже важливим $\epsilon$ проведення моніторингу та визначення чутливості збудників бактеріальних хвороб до антимікробних препаратів (Fotina, 2013. 2014).

\section{Матеріал і методи досліджень}

Дослідження проводилися на базі кафедри ветсанекспертизи, мікробіології, зоогігієни та безпеки i якості продуктів тваринництва Сумського НАУ. Відбір проб для мікробіологічних досліджень проводили в залах інкубаторію, з патологічного матеріалу і приміщень, де утримується птиця різних вікових груп. При цьому враховували поширення хвороби, захворюваність, смертність, летальність, вікові особливості, економічні збитки які хвороби наносять господарствам. Посіви з проб кісткового та головного мозку, серця, печінки, жовчного міхура, м'язів та інших органів проводили на прості, селективні та диференційно - діагностичні поживні середовища.

Для мікробіологічного моніторингу використовували тест - системи фірми R-biopharm, a саме RIDA ® COUNT, Унікальні характеристики запатентованих тест-карток RIDA®COUNT роблять їх не замінними для організації ефективного моніторингу збудників хвороб на будь-якому підприємстві (в рамках НАССР). Ідентифікацію сальмонел і ешерихій проводили методом імуноферментного аналізу за допомогою тест-систем RIDASCREEN $®$ і LOCATE®, відповідно до методичних рекомендацій по використанню тестсистеми LOCATE® і методичними рекомендаціями щодо використання тест-систем RIDASCREEN®. Результати зчитували візуально або після додавання стопреагенту, за допомогою ІФА-фотометра (рідера) при 450 нм. Чутливість до антибіотиків визначали диско - дифузним методом в агар. 


\section{Результати та їх обговорення}

Своїми дослідженнями ми встановили, що сальмонельоз та ешерихіоз поширені інфекції, їх відсоток складає 84,9\% від загальної кількості хвороб птиці. Відсоток збудників сальмонельозу - 54,1\%. Треба звернути увагу що найбільша кількість ізолятів відноситься до серовару S. enteritidis - 16,8\%, які виклика- ють сальмонельозні токсикоінфекції у людини. Збудникі ешерихіозу виділялися у $30,8 \%$ випадках. Ентеротоксигений штам Е. coli O157 ізолювався у 6,1\% від загальної кількості ешерихій, а це є потенційний збудник ешерихіозної токсикоінфекції (табл. 1). Це вказує на необхідність систематичного контролю за наявністю збудників бактеріальних інфекцій на всіх критичних точках виробництва продукції птахівництва.

Таблиия 1

Моніторінг збудників інфекційних хвороб птиці в птахівничих господарствах України, \%

\begin{tabular}{|c|c|c|c|c|c|}
\hline $\begin{array}{c}\text { № } \\
\text { п/п }\end{array}$ & Salmonella (54,1\%) & $\%$ & $15,1 \%$ інша бактеріальна мікрофлора & $\begin{array}{c}\text { Escherichia coli } \\
(30,8 \%)\end{array}$ & \% \\
\hline 1 & S. gallinarum & 9,1 & S. aureus & E.coli O1 & 10,3 \\
\hline 2 & S. pullorum & 10,1 & S. faecalis & E.coli O2 & 1,8 \\
\hline 3 & S. enteritidis & 16,8 & C. jejuni & E.coli O8 & 1,2 \\
\hline 4 & S. typhimurium & 10,1 & C. diversus & E.coli O11 & 0,6 \\
\hline 5 & S. jawa & 0,6 & Y. enterocolitica & E.coli O41 & 0,3 \\
\hline 6 & S. infantis & 1,3 & P. vulgaris & E.coli O55 & 2,3 \\
\hline 7 & S. montevideo & 0,4 & E. agglomerans & E. coli O157 & 6,1 \\
\hline 8 & S. virchow & 5,3 & K. pneumoniae & E. coli O4 & 6,1 \\
\hline 9 & S. london & 0,4 & P. aeruginosa & E. coli 035 & 0,1 \\
\hline 10 & S. arizona & 0,1 & & & \\
\hline
\end{tabular}

При визначенні чутливості ізольованих культур до антибактеріальних препаратів було встановлено високу резистентність ізольованих культур сальмонел до амоксоциліну, клиндамицину, гентаміцину, доксицикліну, егоціну, колістину. Це ми повязуэмо з тривалим використанням данних препаратів в птахівничих господарствах. Чутливими культури були до групи фторхінолонів 3 покоління (енроксилу, цифтіокуру, флорфеніколю) і до препаратів комбінованої дії ТімТіл 250 та сарафлоксацин. Але не було виявлено препарату, до якого б були чутливі всі епізоотично значимі культури бактерій. Використання таких препаратів призводить до накопичення їх в організмі птиці і продукція від такої птиці може мати значну залишкову кількість цих препаратів.

Порівняльні результати чутливості різних сероварів сальмонел до антимікробних препаратів

\begin{tabular}{|c|c|c|c|c|c|c|c|c|c|}
\hline Антибиотики & $\begin{array}{l}\text { S. galli- } \\
\text { naru }\end{array}$ & $\begin{array}{l}\text { S. pullo- } \\
\text { rum }\end{array}$ & $\begin{array}{l}\text { S. enter- } \\
\text { itidis }\end{array}$ & $\begin{array}{l}\text { S. typhi- } \\
\text { murium }\end{array}$ & $\begin{array}{c}S . \\
\text { jawa }\end{array}$ & $\begin{array}{c}S . \\
\text { infantis }\end{array}$ & $\begin{array}{l}\text { S. monte- } \\
\text { video }\end{array}$ & $\begin{array}{l}\text { S vir- } \\
\text { chow }\end{array}$ & $\begin{array}{c}S . \\
\text { london }\end{array}$ \\
\hline Амоксицилін & $\mathrm{p}$ & $\mathrm{p}$ & $\mathrm{p}$ & $\mathrm{p}$ & $\mathrm{p}$ & $\mathrm{p}$ & $\mathrm{p}$ & $\mathrm{p}$ & $\mathrm{p}$ \\
\hline Колістин & $\mathrm{c}$ & $\mathrm{c}$ & $\mathrm{c}$ & $\mathrm{c}$ & $\mathrm{c}$ & $\mathrm{c}$ & $\mathrm{c}$ & $\mathrm{p}$ & $\mathrm{p}$ \\
\hline Флорфеніколь & ч & $\mathrm{Y}$ & $\mathrm{Y}$ & ч & ч & ч & $\mathrm{Y}$ & $\mathrm{Y}$ & $\mathrm{Y}$ \\
\hline Цифтіокур & $\mathrm{Y}$ & $\mathrm{Y}$ & ч & $\mathrm{Y}$ & $\underline{4}$ & $\mathrm{Y}$ & $\mathrm{Y}$ & ч & ч \\
\hline ТімТіл 250 & $\mathrm{Y}$ & $\mathrm{Y}$ & 4 & $\mathrm{Y}$ & $\mathrm{Y}$ & $\mathrm{Y}$ & $\mathrm{Y}$ & $\mathrm{Y}$ & $\mathrm{Y}$ \\
\hline Егоцин & $\mathrm{c}$ & $\mathrm{c}$ & $\mathrm{c}$ & $\mathrm{p}$ & $\mathrm{p}$ & $\mathrm{p}$ & $\mathrm{p}$ & $\mathrm{p}$ & $\mathrm{p}$ \\
\hline Доксициклин & $\mathrm{p}$ & $\mathrm{p}$ & $\mathrm{c}$ & $\mathrm{c}$ & $\mathrm{c}$ & $\mathrm{c}$ & $\mathrm{c}$ & $\mathrm{c}$ & $\mathrm{c}$ \\
\hline Гентаміцин & $\mathrm{p}$ & $\mathrm{p}$ & $\mathrm{p}$ & $\mathrm{p}$ & $\mathrm{p}$ & $\mathrm{p}$ & $\mathrm{p}$ & $\mathrm{p}$ & $\mathrm{p}$ \\
\hline Енроксил & ч & $\mathrm{Y}$ & $\mathrm{Y}$ & ч & $\mathrm{Y}$ & 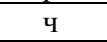 & ч & ч & $ч$ \\
\hline Клиндамицин & $\mathrm{p}$ & $\mathrm{p}$ & $\mathrm{p}$ & $\mathrm{p}$ & $\mathrm{p}$ & $\mathrm{p}$ & $\mathrm{p}$ & $\mathrm{p}$ & $\mathrm{p}$ \\
\hline Сарафлоксацин & प & 4 & $\mathrm{Y}$ & ч & ч & ч & ч & ч & ч \\
\hline
\end{tabular}

Примітка: ч - чутливі, с - слабочутливі, $\mathrm{p}$ - резистентні

Аналогічні дослідження були проведені і з ізолятами ешерихій. При цьому встановили, що вони були чутливі до колістину, фторфеніколю, цефтіокуру, ТімТіл 250, доксоцикліну, енроксилу та сарафлоксацину. Резистентними ізольовані культури ешерихій були до амоксоциліну, клиндаміцину, егоцину, гентаміцину. Це, також, пов'язуємо з тривалим використанням данних препаратів у птахівничих господарствах. У зв'язку з цим вважаємо, що з метою профілактики і лікування бактеріальних хвороб птиці необхідно використовувати лише ті препарати, до яких чутливі не менше 90\% ізольованих культур.
При використанні антимікробних засобів слід брати до уваги i їх можливу побічну дію на організм птиці - токсичний ефект, алергічну реакцію, розвиток дисбактеріозів, виникнення суперінфекції або реакції загострення захворювання. Крім того, необхідно точно встановлювати дози препаратів і розраховувати час їх виведення із організму птиці, бо м'ясо від неї із залишками лікарських препаратів може викликати у людини алергічні реакції, дисбактеріози, пригнічення імуногенезу та інші негативні явища. 
Таблиия 3

Порівняльні результати чутливості різних сероварів ешерихій до антимікробних препаратів

\begin{tabular}{|c|c|c|c|c|c|c|c|c|c|}
\hline Антибиотики & $\begin{array}{l}\overline{0} \\
\ddot{\overline{0}} \\
\dot{0}\end{array}$ & 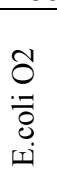 & 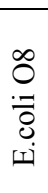 & $\begin{array}{l}= \\
0 \\
: \overline{0} \\
0 \\
0 \\
\dot{0}\end{array}$ & $\begin{array}{l}\vec{\Xi} \\
:= \\
\dot{0} \\
0 \\
\dot{0}\end{array}$ & $\begin{array}{l}n \\
\tilde{0} \\
: \overline{0} \\
0 \\
\dot{0}\end{array}$ & $\begin{array}{l}\hat{n} \\
0 \\
0 \\
0 \\
0 \\
0\end{array}$ & \begin{tabular}{l}
$\infty$ \\
0 \\
0 \\
\hdashline \\
0 \\
0 \\
1
\end{tabular} & $\begin{array}{l}n \\
\text { ô } \\
=\overline{0} \\
\dot{0} \\
\end{array}$ \\
\hline Амоксоцилін & $\mathrm{p}$ & $\mathrm{p}$ & $\mathrm{p}$ & $\mathrm{p}$ & $\mathrm{p}$ & $\mathrm{p}$ & $\mathrm{p}$ & $\mathrm{p}$ & $\mathrm{p}$ \\
\hline Колістин & $\mathrm{Y}$ & $\mathrm{Y}$ & 4 & 4 & $\mathrm{Y}$ & $\mathrm{Y}$ & $\mathrm{Y}$ & $\mathrm{Y}$ & 4 \\
\hline Флорфеніколь & $\mathrm{Y}$ & 4 & 4 & ч & $\mathrm{Y}$ & $\mathrm{Y}$ & $\mathrm{Y}$ & $\mathrm{Y}$ & $\mathrm{Y}$ \\
\hline Цифтіокур & 4 & $\mathrm{Y}$ & 4 & $\mathrm{Y}$ & $\mathrm{Y}$ & $\mathrm{Y}$ & $\mathrm{Y}$ & 4 & 4 \\
\hline ТімТіл 250 & $\mathrm{Y}$ & $\mathrm{Y}$ & 4 & 4 & $\mathrm{Y}$ & $\mathrm{Y}$ & $\mathrm{4}$ & $\mathrm{Y}$ & 4 \\
\hline Егоцин & $\mathrm{Y}$ & 4 & $\mathrm{c}$ & $\mathrm{p}$ & $\mathrm{p}$ & $\mathrm{p}$ & $\mathrm{p}$ & $\mathrm{p}$ & $\mathrm{p}$ \\
\hline Доксоциклін & $\mathrm{Y}$ & $\mathrm{\Psi}$ & 4 & 4 & $\mathrm{Y}$ & $\mathrm{Y}$ & $\mathrm{Y}$ & $\mathrm{Y}$ & 4 \\
\hline Гентаміцин & $\mathrm{p}$ & $\mathrm{p}$ & $\mathrm{p}$ & $\mathrm{p}$ & $\mathrm{p}$ & $\mathrm{p}$ & $\mathrm{p}$ & $\mathrm{p}$ & $\mathrm{p}$ \\
\hline Енроксил & $\mathrm{Y}$ & 4 & 4 & 4 & $\mathrm{Y}$ & $\mathrm{Y}$ & 4 & 4 & 4 \\
\hline Клиндамицин & $\mathrm{p}$ & $\mathrm{p}$ & $\mathrm{p}$ & $\mathrm{p}$ & $\mathrm{p}$ & $\mathrm{p}$ & $\mathrm{p}$ & $\mathrm{p}$ & $\mathrm{p}$ \\
\hline Сарафлоксацин & $\mathrm{Y}$ & $\mathrm{Y}$ & $\mathrm{Y}$ & $\mathrm{Y}$ & $\mathrm{Y}$ & 4 & $\mathrm{Y}$ & $\mathrm{Y}$ & $\mathrm{Y}$ \\
\hline
\end{tabular}

Примітка: ч - чутливі, с - слабочутливі, $\mathrm{p}$ - резистентні

\section{Висновки}

1. Мікробіологічний моніторинг ряду птахівничих господарств України свідчить, що збудники хвороб бактеріальної етіології широко розповсюдженні. Поміж ізольованої мікрофлори найбільшу кількість становили сальмонели $(54,1 \%)$ та ешерихії (30,8\%). Решту $(15,1 \%)$ становили ізольовані культури протею, синьогнійної палички, клебсієл, ієрсиній, кампілобактерій, ентеробактерій, цитробактерій та клостридій. Це вказує на необхідність систематичного контролю за наявністю збудників бактеріальних інфекцій на всіх критичних точках виробництва продукції птахівництва.

2. Поміж ізолятів, які були виділені від хворої птиці та з об'єктів птахівництва, виявили відмінності в їх чутливості до протимікробних засобів 3 числа АДР хіміотерапевтичних засобів, офіційно зареєстрованих у нашій країні. Бактерицидну активність щодо ізольованих культур виявили: колістин, фторфеніколь, цефтіокур, ТімТіл 250, доксоциклін, енроксил та сарафлоксацин.

Перспективи подальших досліджень. Створення та фармако-токсикологічна оцінка хіміотерапевтичних засобів для забезпечення схем ротації вітчизняних препаратів для профілактики бактеріальних інфекцій птиці.

\section{Бібліографічні посилання}

Borisenkova, A.N., Rozhdestvenskaja, T.N. (2003). Ispytanie kompleksnogo preparata na osnove probiotikov i fermenta dlja profilaktiki bakterial'nyh boleznej u ptic. Sb. nauch. tr. Litovskogo vet. Institute, $99-100$.
Aleksandrov, D.E, Migaesh, V.S. (2011). Kompleksnye antibakterial'nye preparaty $\mathrm{V}$ promyshlennom pticevodstve. Veterinarija. 10, 13-15 (in Ukrainian).

Vostroilova, G.A., Bliznecova, G.N., Cheskidova, L.V. (2012). Jeffektivnost' primenenija dioksinora dlja lechenija kolibakterioza u cypljat-brojlerov. Innovacionnye razrabotki i ih osvoenie $\mathrm{v}$ promyshlennom pticevodstve: mater. XVII Mezhdun. konf. Sergiev Posad, 519-521.

Stegnij, B.T., Gljebova, K.V., Petrenchuk, E.P., Bobrovyc'ka, I.A., Majboroda, O.V. (2014). Epizootologichnyj monitoryng bakterial'nyh hvorob ptyci $\mathrm{V}$ Ukrai'ni. nVeterynarna medycyna. Harkiv. 98, 99-102 (in Ukrainian).

Wegener, H.C.(2009). Danish initiatives to improve the safety of meat products. Meat Science.

Dvorskaja, Ju.E., Fotina, A.A. (2012). Programma po snizheniju kolichestva sal'monell $\mathrm{V}$ produktah pticevodstva. Nauchnoe obespechenie agropromyshlennogo proizvodstva: Mezhdunarodnyj nauch.-prakt. sborn. Kursk. 1, 14-17. (in Russian).

Fotina, T.I., Fotina, G.A. (2014). Efektyvnist' zastosuvannja ekologichnyh zasobiv pry vyrobnyctvi produkcii' ptahivnyctva. Problemy zooinzhenerii' ta veterynarnoi' medycyny: Zbirnyk naukovyh prac' Harkivs'koi' derzhavnoi' zooveterynarnoi' akademii'. H.: RVV HDZVA. 28, 2, 14-20 (in Ukrainian).

Fotina, A.A. (2013). Novyj preparat dlja profilaktiki boleznej ptic. Innovacii kak faktor razvitija APK i sel'skih territorij: Sborn. mezhdun. nauch-prakt. konf. Smolensk, 2, 394-399 (in Russian).

Fotina, T.I., Fotina, G.A. (2014). Mikroflora ptashnykiv Nashe ptahivnyctvo. 6 (36), 84-88 (in Ukrainian).

Стаття надійшла до редакиї 6.10.2016 